\title{
Sistem Pakar Diagnosa Penyakit Mata Menggunakan Metode Certainty Factor Berbasis Android
}

\author{
(Android Based Expert System for Eye Diseases Diagnosis using Certainty Factor)
}

\author{
Yogi Permana, I Gede Pasek Suta Wijaya, Fitri Bimantoro \\ Teknik Informatika, Universitas Mataram \\ J1. Majapahit 62, Mataram, Lombok NTB, INDONESIA \\ Email: eightbits21@gmail.com, gpsutawijya@unram.ac.id, bimo@unram.ac.id
}

\begin{abstract}
The Eye is most important sensory organ of the human body if the eyes have disorder or disease then it will be very fatal for human life. So it should be an eye that is an important organ of the body that needs to be maintained in daily health. The purpose of this study is that people can easily diagnose and identify the type of eye disease with symptoms that he suffered using android based applications. In this study the method certainty factor is applied to describe the level of expert confidence to the problem being faced, in this case is eye disease. Calculation of certainty factor values based on the value set by the expert and the value inputted by the application user. The results show that the proposed system can diagnose the disease with an accuracy of $75 \%$ with 15 diseases and 52 symptoms in the diagnosis process.
\end{abstract}

Key words: Expert System, Eye, Certainty factor, Android.

\section{PENDAHULUAN}

Mata adalah suatu panca indra yang sangat penting dalam kehidupan manusia untuk melihat. Jika mata mengalami gangguan yang menyebabkan penyakit mata, hal ini berakibat sangat fatal bagi kehidupan manusia berupa kebutaan mata. Seiring perkembangan teknologi yang sangat pesat, pada bidang kedokteran saat ini telah memanfaatkan teknologi untuk membantu mengatasi penyakit-penyakit yang diderita oleh masyarakat. Pekerjaan yang sangat sibuk dan rumit dalam analisa dari seorang dokter mengakibatkan bidang sistem pakar mulai dimanfaatkan untuk membantu seorang ahli dalam mendiagnosa berbagai macam penyakit.

Sistem pakar merupakan suatu sistem terkomputerisasi yang menirukan seorang pakar dalam mengatasi masalah yang rumit sesuai dengan pengetahuan yang dimilikinya. Penyelesaian masalah dapat diuji dan hasil pengujian tersebut apakah sesuai dengan hasil yang dikerjakan oleh seorang pakar[1]. Salah satu implementasi yang diterapkan sistem pakar dalam bidang kedokteran atau kesehatan adalah sistem pakar. Seorang pakar/ahli dalam hal ini biasanya dokter sering kali menganalisis informasi yang ada dengan ungkapan seperti "mungkin", "kemungkinan besar", "hampir pasti". Untuk mengakomodasi hal ini maka digunakan certainty factor untuk menggambarkan tingkat keyakinan pakar terhadap masalah yang sedang dihadapi[6].

Dalam membangun sistem pakar ini digunakan framework Ionic yang berjalan di sistem operasi Android, Android dengan framework Ionic dipilih karena masyarakat lebih banyak menggunakan sistem operasi ini dibandingkan dengan sistem operasi lain dan juga aplikasi dengan menggukan Ionic sangatlah ringan dan tidak banyak memakan memori. Aplikasi sistem pakar untuk diagnosa penyakit mata menggunakan metode certainty factor ini diharapkan dapat membantu masyarakat dalam mendapatkan informasi seputar mata dan melakukan identifikasi penyakit mata beserta mendapatkan solusi sementara sebelum pengguna berkonsultasi lebih lanjut dengan dokter mata.

\section{PENELITIAN SEBELUMNYA}

Terdapat banyak penelitian sistem pakar yang telah dilakukan dan berhubungan dengan penyakit mata. Dalam penelitian pertama yang menjadi sumber rujukan yaitu Sistem Pakar Diagnosis Penyakit Mata Menggunakan Nä̈ve bayes Classifier. Data yang digunakan pada penelitian ini adalah 15 penyakit dan 52 gejala penyakit mata. persentase kesesuaian diagnose adalah sebesar $83 \%$ dari 12 pasien[2].

Dalam penelitian yang berjudul Neural Network and Decision Tree for eye dieses diagnosis. Data penelitian yang digunakan adalah 13 penyakit mata dan 22 gejala, 50 data pasien digunakan untuk pengujian. Data diambil dari Linsolar Eye Clinic and Odadiki eye clinic, kota Port Harcourt di Nigeria. Metode yang digunakan adalah back propagation. Hasil menunjukkan prosentase kesesuaian diagnosis adalah 92\%[3].

Dalam penelitian yang berjudul Perancangan Sistem Pakar Diagnosa Penyakit pada Mata. Penelitian ini menggunakan konsep forward chaining dengan analisis jenis penyakit mata dan gejalanya melalui pohon biner serta menggunakan Rule Based System sebagai dasar pembuatan sistem pakar penyakit pada mata[4]. 


\section{METODE USULAN}

Desain arsitektur untuk sistem pakar diagnosa penyakit berbasis android dapat dilihat pada Gambar 1 yang menggambarkan hubungan antara elemen-elemen utama dari sistem pakar yang akan dibuat.

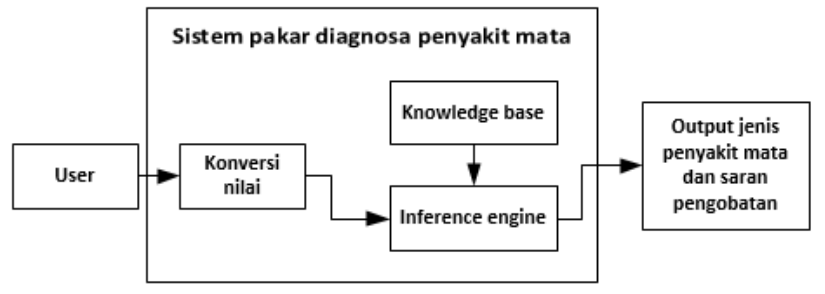

Gambar 1. Blok diagram sistem pakar penyakit mata.

Untuk membangun sistem pakar yang baik diperlukan beberapa komponen, antara lain [1]:

1. Basis Pengetahuan (Knowledge Base)

2. Memori Kerja (Working Memory)

3. Mekanisme Inferensi (Inference Machine)

4. Antar Muka Pengguna (User Interface)

\section{A. Basis Pengetahuan}

Basis pengetahuan merupakan inti dari suatu sistem pakar, yaitu berupa representasi pengetahuan dari pakar dan pengetahuan non-formal, yang bersumber dari buku, artikel, atau jurnal. Basis pengetahuan tersusun atas fakta yang berupa informasi tentang objek, peristiwa, atau situasi, dan kaidah berupa informasi tentang cara untuk membangkitkan suatu fakta baru dari fakta yang telah ada. Berikut merupakan jenis-jenis penyakit dan gejala-gejala dari penyakit mata.

Tabel 1. Gejala penyakit mata[5]

\begin{tabular}{|l|l|}
\hline ID Gejala & Gejala \\
\hline G001 & Mata nyeri hebat \\
\hline G002 & Mata menonjol \\
\hline G003 & Penglihatan kabur \\
\hline G004 & Peka terhadap cahaya \\
\hline G005 & Mata merah \\
\hline G006 & Mata berair \\
\hline G007 & Mata perih \\
\hline G008 & Mata gatal \\
\hline G009 & Kelopak Mata membengkak \\
\hline G010 & Mata ungu \\
\hline G011 & Mata sakit \\
\hline G012 & Air mata berlebihan \\
\hline G013 & Mata tegang \\
\hline G014 & Mata meradang \\
\hline G015 & Mata kering \\
\hline G016 & Mata iritasi \\
\hline
\end{tabular}

\begin{tabular}{|c|c|}
\hline G017 & Mata nyeri bila ditekan \\
\hline G018 & Demam \\
\hline G019 & Menekan kedipan berlebihan \\
\hline G020 & $\begin{array}{l}\text { Sel batang retina sulit berdaptasi diruang } \\
\text { yang remang-remang }\end{array}$ \\
\hline G021 & Pada siang hari penglihatan menurun \\
\hline G022 & $\begin{array}{l}\text { Tidak dapat melihat pada lingkungan } \\
\text { yang kurang bercahaya }\end{array}$ \\
\hline G023 & Pergerakan mata terbatas \\
\hline G024 & Mata tampak mengkilat \\
\hline G025 & $\begin{array}{l}\text { Bola mata membengkak dan tampak } \\
\text { berkabut }\end{array}$ \\
\hline G026 & $\begin{array}{l}\text { Sumber cahaya akan berwarna pelangi } \\
\text { bila memandang lampu neon }\end{array}$ \\
\hline G027 & $\begin{array}{l}\text { Penglihatan yang tadinya kabur lama- } \\
\text { kelamaan menjadi normal }\end{array}$ \\
\hline G028 & Malam hari kesulitan melihat \\
\hline G029 & Siang hari ketajaman mata menurun \\
\hline G030 & Mata silau akan cahaya \\
\hline G031 & Sering ganti kacamata \\
\hline G032 & $\begin{array}{l}\text { Penglihatan ganda pada salah satu sisi } \\
\text { mata }\end{array}$ \\
\hline G033 & Lensa mata membengkak \\
\hline G034 & $\begin{array}{l}\text { Berbentuk keropeng pada kelopak mata } \\
\text { ketika bangun pada siang hari }\end{array}$ \\
\hline G035 & Penglihatan menurun pada ruang gelap \\
\hline G036 & Penglihatan menurun pada malam hari \\
\hline G037 & Keluarnya cairan kotoran dari mata \\
\hline G038 & Berbaliknya bulu mata \\
\hline G039 & $\begin{array}{l}\text { Pembengkakan kelenjar getah bening } \\
\text { didepan telinga }\end{array}$ \\
\hline G040 & Munculnya garis parutan pada kornea \\
\hline G041 & $\begin{array}{l}\text { Komplikasi pada,telinga,hidung dan } \\
\text { tenggorokan }\end{array}$ \\
\hline G042 & Mata mempersempit, perubahan bentuk \\
\hline G043 & $\begin{array}{l}\text { Benjolan pada mata bagian atas atau } \\
\text { bawah }\end{array}$ \\
\hline G044 & $\begin{array}{l}\text { Gangguan penglihatan pada salah satu } \\
\text { mata }\end{array}$ \\
\hline G045 & Garis mata lurus terlihat bergelombang \\
\hline G046 & Mata tidak nyeri \\
\hline G047 & Mata melihat melayang-layang \\
\hline G048 & Mata melihat kilatan cahaya \\
\hline G049 & Seperti ada benda asing di mata \\
\hline G050 & Sakit kepala \\
\hline G051 & $\begin{array}{l}\text { Riwayat penyakit menular seksual pada } \\
\text { ibu }\end{array}$ \\
\hline G052 & Mata membengkak \\
\hline
\end{tabular}


Tabel 2. Penyakit mata[5]

\begin{tabular}{|l|l|}
\hline ID Penyakit & Nama Penyakit \\
\hline PM001 & Xerophtalmania \\
\hline PM002 & Selulitis Orbitalitas \\
\hline PM003 & Glaukoma \\
\hline PM004 & Dakriosistitis \\
\hline PM005 & Katarak \\
\hline PM006 & Konjungtivitis \\
\hline PM007 & Retinitis Pigmentosa \\
\hline PM008 & Trakoma \\
\hline PM009 & Oveitis \\
\hline PM010 & Hordeolum \\
\hline PM011 & Degenerasi Makula \\
\hline PM012 & Ablasio Retina \\
\hline PM013 & Pterygium \\
\hline PM014 & Miopi \\
\hline PM015 & Oftalmia Neonatorium \\
\hline
\end{tabular}

\section{B. Pembentukan Basis Aturan}

Dari hasil analisis jenis penyakit mata dan gejalanya melalui studi litelatur dan wawancara ahli, maka dapat dibuat sebuah RBS (Rule Based System). RBS merupakan perangkat lunak yang menyajikan keahlian pakar dalam bentuk aturan-aturan pada suatu domain tertentu untuk menyelesaikan suatu permasalahan. RBS adalah model sederhana yang bisa diadaptasi ke banyak masalah. RBS ini dapat dijadikan dasar pembuatan pada sistem pakar diagnosa penyakit pada mata, model RBS dapat dilihat pada Tabel 3.

\section{Mesin Inferensi}

Inferensi merupakan proses untuk menghasilkan informasi dari fakta yang diketahui atau diasumsikan. Inferensi adalah konklusi logis (logical conclusion) atau implikasi berdasarkan pada informasi yang tersedia. Dalam sistem pakar, proses inferensi dilakukan dalam suatu modul yang disebut Inference engine (mesin inferensi). Ketika representasi pengetahuan pada bagian knowledge base telah lengkap maka referensi pengetahuan tersebut telah siap digunakan. Secara umum ada dua teknik utama yang digunakan dalam mekanisme inferensi untuk pengujian aturan yaitu:

\section{1) Penalaran Maju (Forward Chaining)}

Forward chaining merupakan metode inferensi yang melakukan penalaran dari suatu masalah kepada solusinya. Proses diulang sampai ditemukan suatu hasil. Jika klausa premis sesuai dengan situasi (bernilai TRUE), maka proses akan menyatakan konklusi.

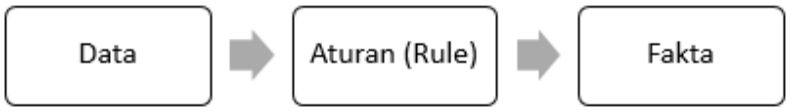

Gambar 2. Penalaran maju (Forward Chaining).

2) Penalaran Mundur (Backward Chaining)

Penalaran mundur disebut juga goal-driven reasoning, Tujuan dari inferensi ini adalah mengambil pilihan terbaik dari banyak kemungkinan. Metode inferensi runut balik ini cocok digunakan untuk memecahkan masalah diagnosis[7].

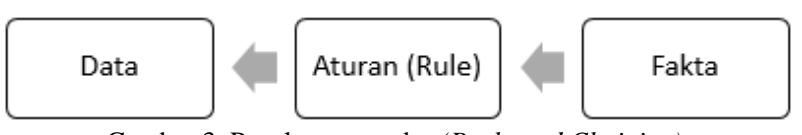

Gambar 3. Penalaran mundur (Backward Chaining).

Tabel 3. Penyakit mata dan gejalanya[5]

\begin{tabular}{|c|c|c|}
\hline $\begin{array}{l}\text { ID } \\
\text { Penyakit }\end{array}$ & Nama Penyakit & Nomor Gejala \\
\hline PM001 & Xerophtalmania & G020, G021, G022 \\
\hline PM002 & Selulitis Orbitalitas & $\begin{array}{l}\text { G001, G002, G023, } \\
\text { G009, G024, G005, } \\
\text { G010, G018, G025 }\end{array}$ \\
\hline PM003 & Glaukoma & $\begin{array}{l}\text { G026, G011, G052, } \\
\text { G027, G019 }\end{array}$ \\
\hline PM004 & Dakriosistitis & G012, G001, G052 \\
\hline PM005 & Katarak & $\begin{array}{l}\text { G028, G021, G030, } \\
\text { G031, G032, G01, } \\
\text { G033 }\end{array}$ \\
\hline PM006 & Konjungtivitis & $\begin{array}{l}\text { G006, G001, G008, } \\
\text { G003, G004, G034 }\end{array}$ \\
\hline РM007 & $\begin{array}{l}\text { Retinitis } \\
\text { Pigmentosa }\end{array}$ & G035, G036, G009 \\
\hline PM008 & Trakoma & $\begin{array}{l}\text { G037, G009, G038, } \\
\text { G039, G040, G041 }\end{array}$ \\
\hline PM009 & Oveitis & $\begin{array}{l}\text { G014, G006, G004, } \\
\text { G042, G043 }\end{array}$ \\
\hline PM010 & Hordeolum & $\begin{array}{l}\text { G005, G001, G006, } \\
\text { G004 }\end{array}$ \\
\hline PM011 & Degenerasi Makula & G044, G045, G046 \\
\hline PM012 & Ablasio Retina & $\begin{array}{l}\text { G047, G048, G003, } \\
\text { G013 }\end{array}$ \\
\hline PM013 & Pterygium & $\begin{array}{l}\text { G043, G005, G016, } \\
\text { G015, G006, G049, } \\
\text { G003 }\end{array}$ \\
\hline PM014 & Miopi & $\begin{array}{l}\text { G001, G007, G012, } \\
\text { G050 }\end{array}$ \\
\hline PM015 & $\begin{array}{l}\text { Oftalmia } \\
\text { Neonatorium }\end{array}$ & $\begin{array}{l}\text { G005, G009, G017, } \\
\text { G051, G003 }\end{array}$ \\
\hline
\end{tabular}

\section{Antar Muka Pengguna}

Antar Muka Pengguna, sistem pakar menggantikan seorang pakar dalam situasi tertentu, maka sistem harus menyediakan pendukung yang diperlukan oleh pemakai yang tidak memahami masalah teknis. Sistem pakar juga 
menyediakan komunikasi antar sistem dan pemakaianya (user) yang disebut sebagai antar muka. Antar muka yang efektif dan ramah penggunaan (user-friendly) penting sekali terutama bagi pemakai yang tidak ahli dalam bidang yang diterapkan pada sistem pakar.

\section{E. Certainty factor}

Teori certainty factor $(\mathrm{CF})$ diusulkan oleh Shortlife dan Buchanan pada 1975 untuk mengakomodasi ketidakpastian pemikiran seorang pakar. Pembuatan sistem pakar ini menggunakan teknik wawancara ahli dengan menginterpretasi "term" dari pakar yang selanjutnya diubah menjadi nilai $\mathrm{CF}$ tertentu. Tabel 4 merupakan uncertain term dari seorang pakar yang dikonversi menjadi sebuah nilai $\mathrm{CF}$.

Tabel 4. Nilai evidence tingkat keyakinan pakar

\begin{tabular}{|l|l|}
\hline Nilai CF & Frase \\
\hline-1.0 & Pasti tidak \\
\hline-0.8 & Hampir pasti tidak \\
\hline-0.6 & Kemungkinan besar tidak \\
\hline-0.4 & Mungkin tidak \\
\hline-0.2 Sampai 0.2 & Tidak tahu \\
\hline 0.4 & Mungkin \\
\hline 0.6 & Kemungkinan besar \\
\hline 0.8 & Hampir pasti \\
\hline 1.0 & Pasti \\
\hline
\end{tabular}

Perhitungan rule certainty factor dapat dipresentasikan sebagai berikut:

$$
\begin{aligned}
& \text { IF E1 AND E2 ... AND En THEN H (CF Rule) } \\
& \text { Atau } \\
& \text { IF E1 AND E2 ... OR En THEN H (CF Rule) }
\end{aligned}
$$

dimana:

E1...E2 : Fakta - fakta (Evidence) yang ada

$$
\mathrm{H} \quad \text { : Hipotesis atau konklusi yang dihasilkan }
$$

CF Rule : Tingkat keyakinan terjadinya hipotesis $\mathrm{H}$ akibat adanya fakta - fakta E1 ... En

Perhitungan certainty factor gabungan dengan evidence kombinasi dua buah rule dengan evidence berbeda (E1 dan E2), tetapi hipotesis sama adalah sebagai berikut:

$C F(C F 1, C F 2)=C F 1+C F 2(1-C F 1)$ untuk $C F 1>0$ dan $\mathrm{CF} 2>0$

$$
C F(C F 1, C F 2)=\frac{(C F 1+C F 2)}{1-(\min [|C F 1|,|C F 2|])} \text { untuk } C F 1>0 \text { atau }
$$

$C F(C F 1, C F 2)=C F 1+C F 2(1+C F 1)$ untuk CF1 $<0$ dan $\mathrm{CF} 2<0$

dimana:

$\begin{array}{ll}\text { CF1 } & \text { : Nilai CF dari evidence } 1 \text { (pertama). } \\ \text { CF2 } & \text { Nilai CF dari evidence } 2 \text { (kedua). }\end{array}$

\section{$\mathrm{CF}(\mathrm{CF} 1, \mathrm{CF} 2)$ : Hasil Nilai $\mathrm{CF}$ gabungan dari evidence yang ada.}

Sebelum melakukan pengimplementasian sistem, dilakukan wawancara pakar untuk menilai kebutuhan nilai $\mathrm{CF}$ dari gajala dan penyakit yang sudah dijabarkan, dimana dalam penentuan nilai $\mathrm{CF}$ ini pakar memberikan nilai sesuai dengan nilai tingkat keyakinan pakar (Tabel 4) terhadap gejala yang mengakibatkan penyakit. yang mana nantinya data tersebut akan menjadi aturan data atau rule (lihat Lampiran A untuk nilai cf rule).

Pada Gambar 4 merupakan alur proses perhitungan nilai CF. Dimana proses perhitungan dimulai dengan memilih fakta gejala, apabila fakta gejala sudah selesai dipilih maka nilai-nilai CF dari fakta gejala yang telah dipilih akan dihitung dengan rumus kombinasi (gabungan) apabila proses perhitungan telah selesai maka akan ditampilkan nilai CF dari gabungan fakta-fakta yang telah dipilih. Proses perhitungan akan terus berlangsung sampai semua nilai CF dari fakta gejala yang telah dipilih terhitung semua.

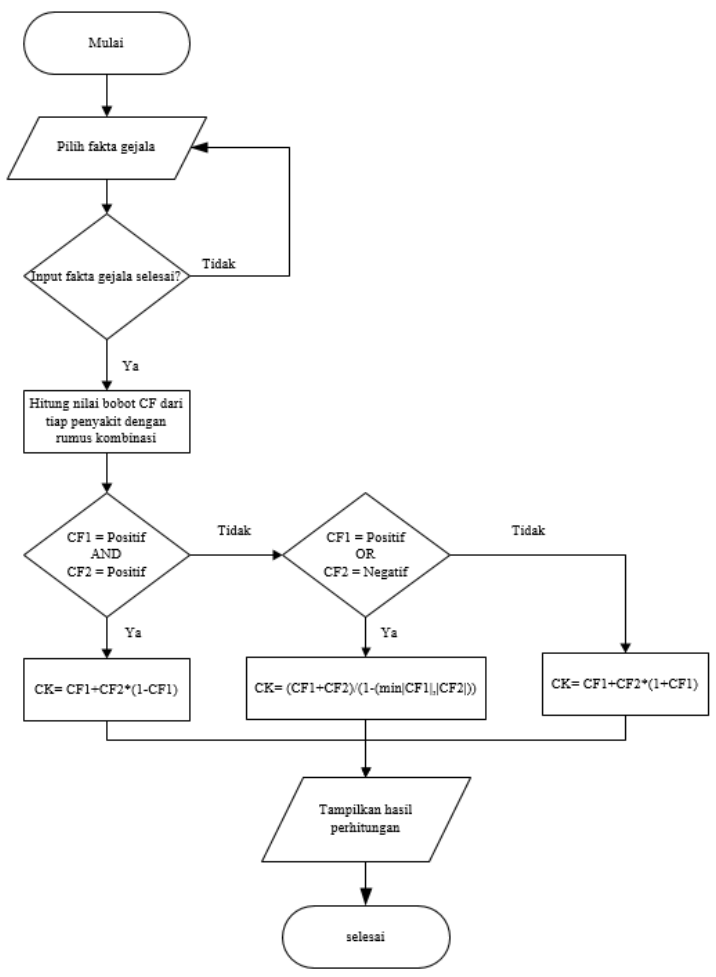

Gambar 4. Alur proses perhitungan nilai cf

Berikut merupakan contoh dari perhitungan nilai $\mathrm{CF}$, Pengguna aplikasi memilih fakta-fakta atau gejala-gejala yanga diderita berupa "Seperti ada benda asing di mata (G049)", "Mata berair (G006)", dan "Penglihatan kabur (G003)". Dari data gejala yang telah dipilih maka akan dikelompokan penyakit apa saja yang mungkin diderita oleh pengguna dengan gejala-gejalanya yang telah dipilih tersebut sehingga dapat dibuatkan tabel seperti pada Tabel 5. 
Tabel 5. Pengelompokan data berdasarkan fakta yang dipilih

\begin{tabular}{|c|c|c|}
\hline Gejala & Nilai CF & Penyakit \\
\hline Penglihatan kabur (G003) & -0.8 & \multirow{2}{*}{ Konjungtivitis } \\
\hline Mata berair (G006) & 1 & \\
\hline Penglihatan kabur (G003) & 0.8 & Ablasio Retina \\
\hline Penglihatan kabur (G003) & 0.4 & \multirow{3}{*}{ Pterygium } \\
\hline Mata berair (G006) & 0.6 & \\
\hline $\begin{array}{l}\text { Seperti ada benda asing di } \\
\text { mata (G049) }\end{array}$ & 0.8 & \\
\hline Penglihatan kabur (G003) & 0.6 & $\begin{array}{l}\text { Oftalmia } \\
\text { Neonatorium }\end{array}$ \\
\hline Mata berair (G006) & -0.4 & Hordeolum \\
\hline Mata berair (G006) & 0.6 & Oveitis \\
\hline
\end{tabular}

Dapat dihitung dengan menggunakan persamaan (3-5):

1. Untuk penyakit Konjungtivitis

- Dikarenakan kedua fakta nilai CF-nya bernilai positif dan negatif maka akan digunakan persamaan (4).

- $\mathrm{CF}$ combine $\mathrm{CF} 1,2=(\mathrm{CF} 1+\mathrm{CF} 2) /(1-$ $(\min [\mathrm{CF} 1, \mathrm{CF} 2]))$

$=(-0.8+1) /(1-(\min [-0.8,1]))$

$=0.2 /(1-(-0.8))$

$=0.11$

2. Untuk Penyakit Ablasio Retina

- Dikarenakan hanya terdapat satu data fakta maka nilai CF fakta tersebut akan langsung menjadi nilai CF akhir dari penyakit Ablasio Retina.

- $\quad$ Nilai $\mathrm{CF}=0.8$

3. Untuk Penyakit Pterygium

- Dikarenakan seluruh fakta nilai CF-nya bernilai positif maka akan digunakan persamaan (3).

- CFcombine CF1,2 = CF1 + CF2 (1-CF1)

$=0.4+0.6(1-0.4)$

$=0.4+0.36$

$=0.76 \Rightarrow$ menjadi nilai CF1 yang baru

- CFcombine CF1baru,2 = CF1baru + CF2 (1CF1baru)

$=0.76+0.8(1-0.76)$

$=0.76+0.192$

$=0.95$

4. Untuk Penyakit Oftalmia Neonatorium

- Dikarenakan hanya terdapat satu data fakta maka nilai CF fakta tersebut akan langsung menjadi nilai $\mathrm{CF}$ akhir dari penyakit Oftalmia Neonatorium.

- $\quad$ Nilai $\mathrm{CF}=0.6$
5. Untuk Penyakit Hordeolum

- Dikarenakan hanya terdapat satu data fakta maka nilai CF fakta tersebut akan langsung menjadi nilai $\mathrm{CF}$ akhir dari penyakit Hordeolum.

- Nilai $\mathrm{CF}=-0.4$

6. Untuk Penyakit Oveitis

- Dikarenakan hanya terdapat satu data fakta maka nilai CF fakta tersebut akan langsung menjadi nilai $\mathrm{CF}$ akhir dari penyakit Oveitis.

- $\quad$ Nilai $\mathrm{CF}=0.6$

Dari perhitungan diatas dapat dihasilkan nilai tertinggi adalah 0.95 yang merupakan penyakit Pterygium.

\section{IMPLEMENTASI SISTEM}

Implementasi sistem pakar diagnosa penyakit mata dilakukan dengan mewawancarai pakar dalam hal ini adalah dokter spesialis penyakit mata yang akan menentukan nilai CF dari masing-masing gejala yang menyebabkan berbagai macam penyakit yang telah dijabarkan pada Tabel 3.

Dengan nilai CF yang telah ditentukan oleh dokter maka akan dihitung nilai kepastian yang merupakan kemungkinan terjadinya suatu penyakit. Pada Gambar 5 merupakan skema alur program diagnosa penyakit secara umum.

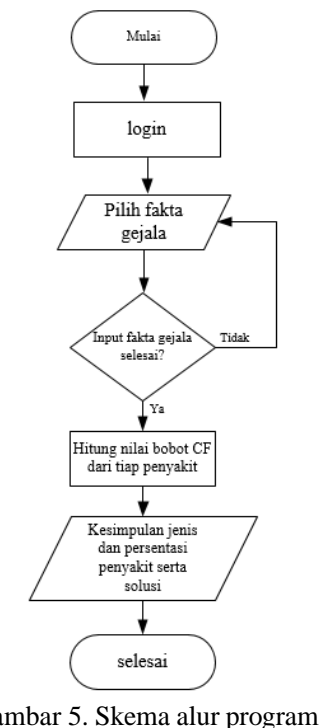

Pada sistem pakar diagnosa penyakit mata Untuk melakukan diagnosa user diharuskan login terlebih dahulu. Proses login dilakukan untuk merekam history dari proses diagnosa user. Pada Gambar 6 merupakan Tampilan halaman login aplikasi sistem pakar.

Kemudian jika validasi berhasil, user akan langsung diarahkan ke halaman diagnosa. Pada halaman ini user dapat memilih gejala-gejala apa saja yang diderita apanila telah selesai memilih gejala maka selanjutnya dengan menekan tombol diagnosa seperti pada Gambar 7 . 


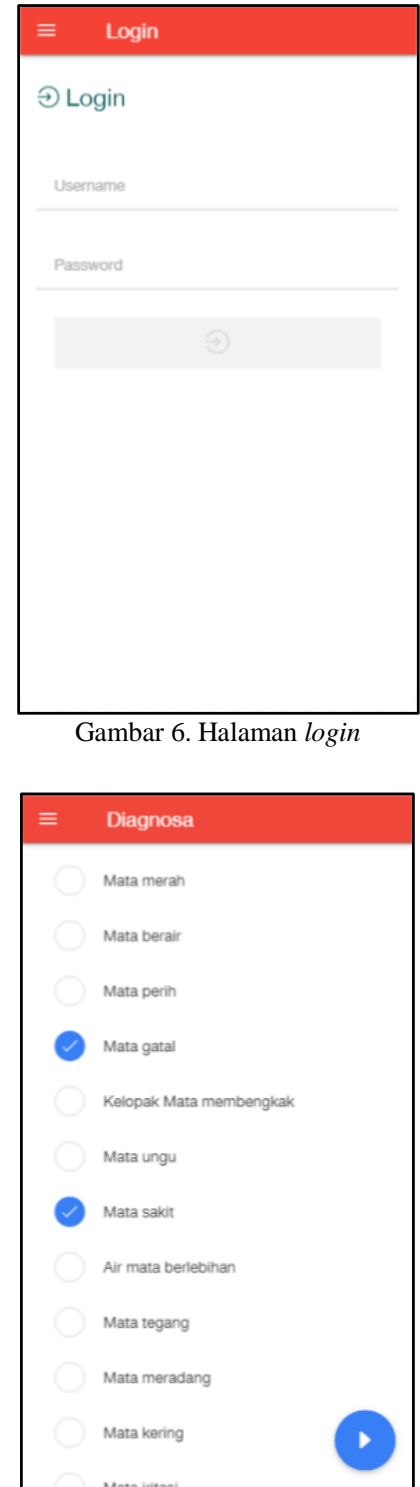

Gambar 7. Halaman diagnosa

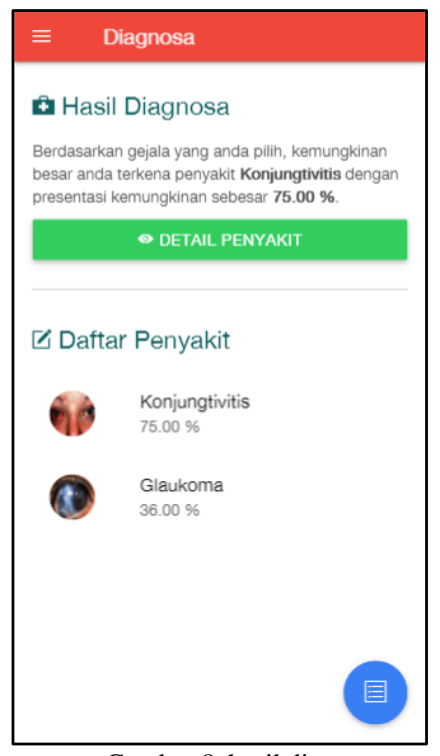

Gambar 8. hasil diagnose
Setelah menekan tombol diagnosa maka akan ditampilkan hasil diagnosa berupa kemungkinan penyakit apa yang diderita oleh user beserta keterangan penyakit dan solusi yang dianjurkan dari penyakit tersebut seperti pada Gambar 8.

\section{HASIL PENGUJIAN DAN DISKUSI}

Setelah melakukan pengimplementasian sistem maka selanjutnya yang dilakukan adalah pengujian sistem. Berikut merupakan hasil beberapa pengujian dari sistem pakar diagnosa penyakit mata menggunakan metode certainty factor berbasis android.

Pada pengujian akurasi terdapat 12 data random yang akan uji pada 3 kali percobaan. Pada percobaan ini pada setiap data uji dilakukan penginputan seluruh data dengan urutan yang random atau berbeda sebanyak 3 kali. Pada Tabel 6 merupakan tabel yang berisi rekapitulasi dari hasil diagnosa data random yang diujikan pada sistem yang dibandingkan dengan hasil diagnosa yang didapatkan dari wawancara pakar untuk menunjukkan ketepatan aplikasi.

Tabel 6. Hasil data ujicoba sistem

\begin{tabular}{|c|c|c|c|}
\hline $\begin{array}{c}\text { Data } \\
\text { Uji }\end{array}$ & Diagnosa Dokter & Diagnosa Sistem & Hasil \\
\hline 1 & $\begin{array}{c}\text { Selulitis } \\
\text { Orbitallitas }\end{array}$ & $\begin{array}{c}\text { Selulitis } \\
\text { Orbitallitas }\end{array}$ & Tepat \\
\hline 2 & Pterygium & Pterygium & Tepat \\
\hline 3 & $\begin{array}{c}\text { Selulitis } \\
\text { Orbitallitas }\end{array}$ & $\begin{array}{c}\text { Selulitis } \\
\text { Orbitallitas }\end{array}$ & Tepat \\
\hline 4 & Dakriosistitis & Dakriosistitis & Tepat \\
\hline 5 & Pterygium & Pterygium & Tepat \\
\hline 6 & Konjungtivitis & Konjungtivitis & Tepat \\
\hline 7 & $\begin{array}{c}\text { Selulitis } \\
\text { Orbitallitas }\end{array}$ & $\begin{array}{c}\text { Selulitis } \\
\text { Orbitallitas }\end{array}$ & Tepat \\
\hline 8 & Glukoma & $\begin{array}{c}\text { Selulitis } \\
\text { Orbitallitas }\end{array}$ & $\begin{array}{c}\text { Tidak } \\
\text { Tepat }\end{array}$ \\
\hline 9 & Xerophtalmania & $\begin{array}{c}\text { Selulitis } \\
\text { Orbitallitas }\end{array}$ & $\begin{array}{c}\text { Tidak } \\
\text { tepat }\end{array}$ \\
\hline 10 & Uveitis & Ablasio Retina & $\begin{array}{c}\text { Tidak } \\
\text { tepat }\end{array}$ \\
\hline 11 & Katarak & Katarak & Tepat \\
\hline 12 & $\begin{array}{c}\text { Oftalmia } \\
\text { Neonatorum }\end{array}$ & $\begin{array}{c}\text { Oftalmia } \\
\text { Neonatorum }\end{array}$ & Tepat \\
\hline
\end{tabular}

Dari Tabel 6 dapat diketahui nilai akurasi sistem pakar untuk mendiagnosis penyakit mata adalah sebesar $75 \%$ dimana dari 12 data uji terdapat 9 data dengan hasil tepat yang mana menunjukan hasil uji random sudah tepat dengan hasil uji dari pakar. Pada Tabel 6 pula terdapat tiga data uji dengan hasil tidak tepat antara hasil uji dokter dan uji sistem, yaitu pada data nomor 8 dengan hasil diagnosa dokter yaitu Glaukoma dan hasil diagnosa sistem adalah Selulitis Orbitallitas, data nomor 9 dengan hasil diagnosa dokter yaitu Xerophtalmania dan hasil diagnosa sistem adalah Selulitis Orbitallitas serta data nomor 10 dengan hasil diagnosa dokter yaitu Uveitis dan hasil diagnosa sistem adalah Ablasio Retina. 
Ketidaksesuaian yang terjadi pada hasil diagnosa dokter dan sistem disebabkan oleh perhitungan nilai $\mathrm{CF}$ suatu gejala dapat mempengaruhi lebih dari satu penyakit, yang mengakibatkan perhitungan nilai $\mathrm{CF}$ terhadap penyakit tidak sesuai dan diagnosa penyakit dari sistem tidak sesuai dengan diagnosa dari dokter.

Pada Tabel 6 ketidaksesuaian diagnosa penyakit dari sistem dan dokter ada pula hasil diagnosa penyakit dokter yang sesuai dengan diagnosa sistem namun nilai CF dari penyakit tidak begitu tinggi yang mengakibatkan penyakit lain dengan nilai $\mathrm{CF}$ lebih tinggi yang dijadikan kesimpulan pada sistem.

Pengujian selanjutnya adalah pengujian kuesioner yang dilakukan dengan menyebar kuesioner pada 30 responden yang dipilih secara acak untuk mengukur kualitas sistem dari sisi pengguna. Representasi grafik dari keseluruhan hasil pengujian kuesioner dapat dilihat pada Gambar 9.

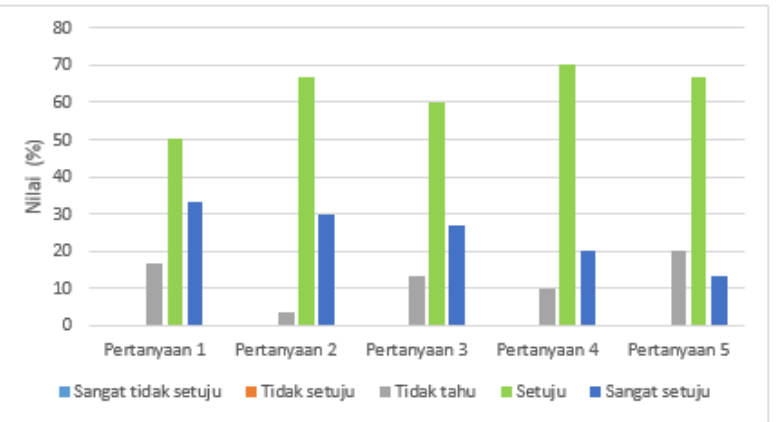

Gambar 9. Grafik persentase jawaban responden.

Sedangkan, hasil dari perhitungan rata-rata keseluruhan jawaban responden terhadap pertanyaan yang diajukan dapat dilihat pada Gambar 10 berikut.

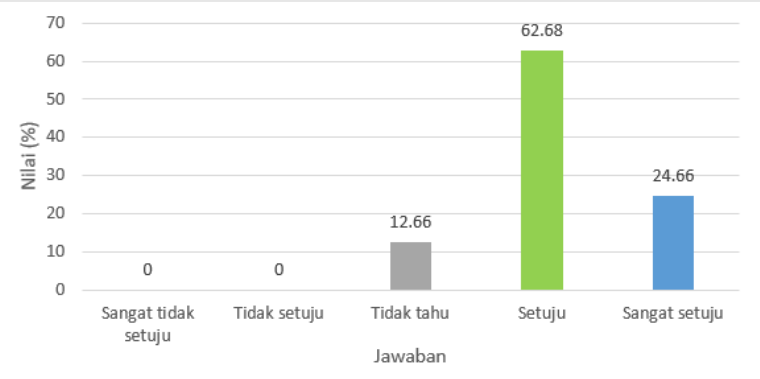

Gambar 10. Grafik persentase rata-rata jawaban responden.

Dari Gambar 10 dapat disimpulkan bahwa sebesar 87.34\% responden pengguna sistem setuju bahwa aplikasi sistem pakar sudah menarik dari aspek tampilan, mudah digunakan, dapat memberikan informasi mengenai diagnosa penyakit mata, dapat digunakan sebagai penanganan dini penyakit mata dan gejala serta penyakit yang disajikan pada aplikasi ini sudah sesuai dengan kenyataan.

\section{KESIMPULAN DAN SARAN}

A. Kesimpulan

Kesimpulan yang dapat diambil dari hasil implementasi:

1. Sistem Pakar Diagnosa Penyakit Mata Menggunakan Metode Certainty factor Berbasis Android yang telah dibuat memiliki tingkat keakuratan diagnosa sebesar $75 \%$ dengan rincian 15 penyakit dan 52 gejala.

2. Sistem Pakar Diagnosa Penyakit Mata Menggunakan Metode Certainty factor Berbasis Android dapat digunakan untuk mendiagnosa penyakit mata dengan tingkat kepercayaan yang telah ditentukan oleh pakar terhadap gejala-gejala yang mempengaruhi probabilitas terjadinya suatu penyakit mata.

3. Sistem ini akan optimal jika seorang atau sekelompok pakar dalam hal ini dokter ahli telah mendefinisikan secara jelas nilai faktor kepastian setiap gejala penyakit terhadap kemungkinan terjadinya penyakit mata.

\section{B. Saran}

Dalam pengembangan aplikasi Sistem Pakar Diagnosa Penyakit Mata terdapat beberapa saran yang membangun bagi penulis untuk mengembangkan aplikasi selanjutnya. Beberapa saran antara lain:

1. Untuk pengembangan selanjutnya, sistem ini dapat dikembangkan dengan menggunakan metode yang berbeda atau mengkombinasikan metode Certainty factor dengan metode lain untuk memperoleh tingkat keyakinan yang lebih optimal.

2. Untuk pengembangan selanjutnya, sistem dapat diterapkan pada platform seperti lain sepeerti IOS, Windows Phone.

\section{DAFTAR PUSTAKA}

[1] Iswanti, H. D., Sistem Pakar dan Pengembangannya, Yogyakarta : Graha Ilmu, 2008.

[2] Setiawan W., Sofie R., "Sistem Pakar Diagnosis Penyakit Mata Menggunakan Naïvebayes Classifier" in Seminar Nasional Sains dan Teknologi, Universitas Muhammadiyah Jakarta, 2014.

[3] Kabari, LG and Nwachukwu, EO. (2012 Dec 5). Neural Networks and Decision Trees For Eye Diseases Diagnosis [online]. Available: http://dx.doi.org/10.5772/51380.

[4] Erianto, "Perancangan Sistem Pakar Diagnosa Penyakit Pada Mata", J. TIME. Vol II No. 2, 2013.

[5] Ilyas, S., Ilmu Penyakit Mata Edisi Kedua, Jakarta : Balai Penerbit FKUI, 2006.

[6] T.Sutojo., Edy Mulyanto., Vincen Suhartono., Jakarta Kecerdasan Buatan, Andi Offset, 2010.

[7] Kusrini., Sistem Pakar Teori dan Aplikasi, Yogyakarta : Andi Yogyakarta, 2006. 


\section{LAMPIRAN A \\ Nilai CF Rule}

\begin{tabular}{|c|c|c|c|}
\hline No & Penyakit mata & Jenis Gejala & CF Rule \\
\hline \multirow{3}{*}{1} & \multirow{3}{*}{ Xerophtalmania } & $\begin{array}{l}\text { Sel batang retina sulit berdaptasi diruang yang remang-remang } \\
(\mathrm{G} 020)\end{array}$ & 0.1 \\
\hline & & Pada siang hari penglihatan menurun (G021) & -1 \\
\hline & & $\begin{array}{l}\text { Tidak dapat melihat pada lingkungan yang kurang bercahaya } \\
\text { (G022) }\end{array}$ & 0.6 \\
\hline \multirow{9}{*}{2} & \multirow{9}{*}{ Selulitis Orbitalitas } & Mata nyeri hebat (G001) & 1 \\
\hline & & Mata menonjol (G002) & 1 \\
\hline & & Pergerakan mata terbatas (G023) & 1 \\
\hline & & Kelopak Mata membengkak (G009) & 1 \\
\hline & & Mata tampak mengkilat (G024) & -1 \\
\hline & & Mata merah (G005) & 1 \\
\hline & & Mata ungu (G010) & -1 \\
\hline & & Demam (G018) & 0.4 \\
\hline & & Bola mata membengkak dan tampak berkabut (G025) & 0.4 \\
\hline \multirow{5}{*}{3} & \multirow{5}{*}{ Glaukoma } & $\begin{array}{l}\text { Sumber cahaya akan berwarna pelangi bila memandang lampu } \\
\text { neon (G026) }\end{array}$ & 1 \\
\hline & & Mata sakit (G011) & 1 \\
\hline & & Mata membengkak (G052) & -0.4 \\
\hline & & $\begin{array}{l}\text { Penglihatan yang tadinya kabur lama- kelamaan menjadi } \\
\text { normal (G027) }\end{array}$ & -1 \\
\hline & & Menekan kedipan berlebihan (G019) & -0.6 \\
\hline \multirow{3}{*}{4} & \multirow{3}{*}{ Dakriosistitis } & Air mata berlebihan (G012) & 1 \\
\hline & & Mata nyeri hebat (G001) & 0.4 \\
\hline & & Mata membengkak (G052) & -0.8 \\
\hline \multirow{6}{*}{5} & \multirow{6}{*}{ Katarak } & Malam hari kesulitan melihat (G028) & -0.6 \\
\hline & & Pada siang hari penglihatan menurun (G021) & 0.6 \\
\hline & & Mata silau akan cahaya (G030) & 0.8 \\
\hline & & Sering ganti kacamata (G031) & 0.6 \\
\hline & & Mata nyeri hebat (G001) & -0.8 \\
\hline & & Lensa mata membengkak (G033) & 0.4 \\
\hline \multirow{4}{*}{6} & \multirow{4}{*}{ Konjungtivitis } & Mata berair (G006) & 1 \\
\hline & & Mata nyeri hebat (G001) & 0.4 \\
\hline & & Mata gatal (G008) & 0.4 \\
\hline & & Penglihatan kabur (G003) & -0.8 \\
\hline
\end{tabular}




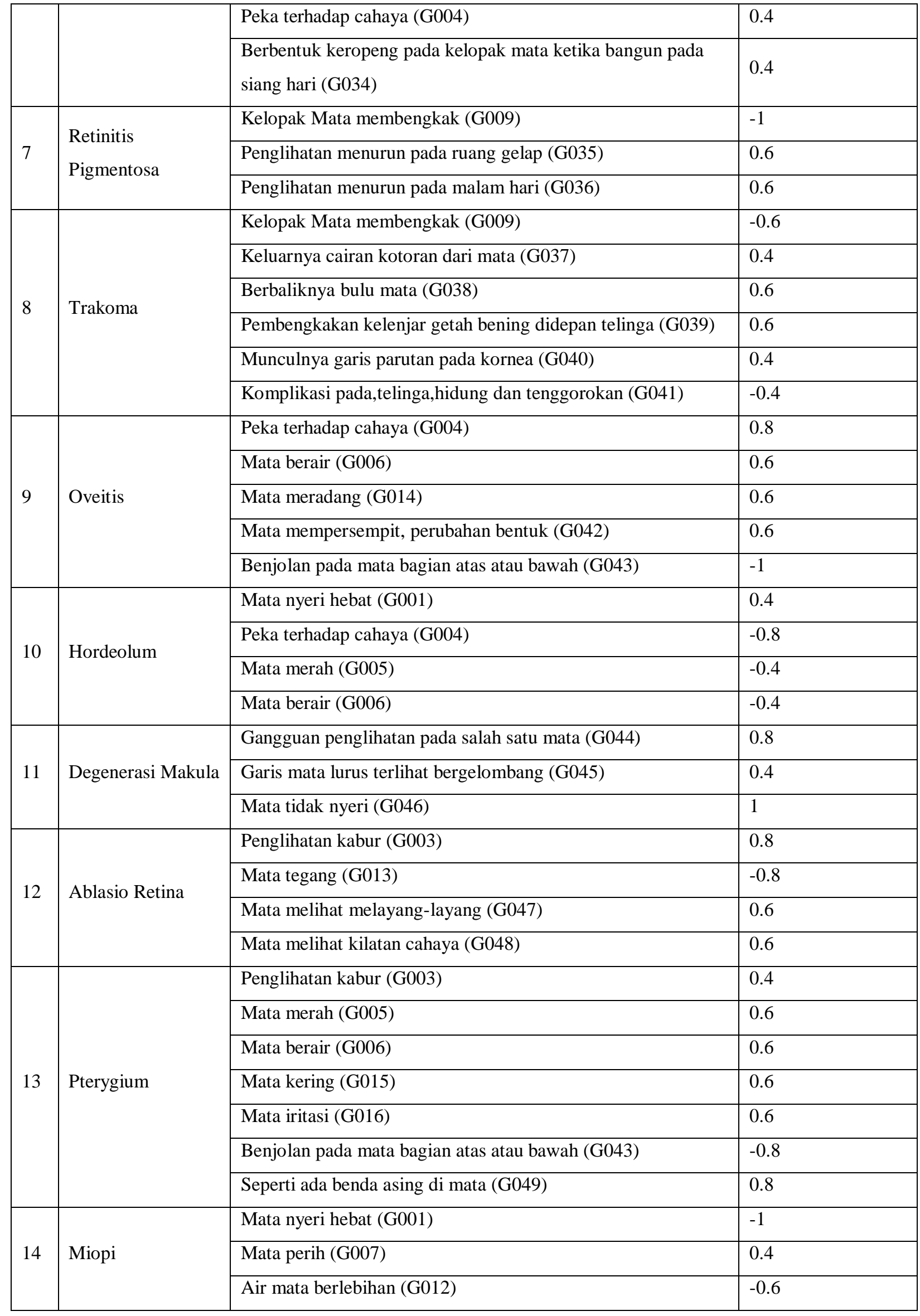




\begin{tabular}{|l|l|l|l|}
\hline & & Sakit kepala (G050) & 0.4 \\
\hline \multirow{4}{*}{15} & \multirow{4}{*}{$\begin{array}{l}\text { Oftalmia } \\
\text { Neonatorium }\end{array}$} & Penglihatan kabur (G003) & 0.6 \\
\cline { 3 - 4 } & Mata merah (G005) & 0.6 \\
\cline { 3 - 4 } & Kelopak Mata membengkak (G009) & 0.6 \\
\cline { 3 - 4 } & Mata nyeri bila ditekan (G017) & 0.4 \\
\cline { 3 - 4 } & Riwayat penyakit menular seksual pada ibu (G051) & 0.8 \\
\hline
\end{tabular}

